ngắn được phát hiện qua siêu âm đường âm đạo chỉ là $3,3 \%$; thấp hơn so với nghiên cứu của chúng tôi. Tuy nhiên số lượng thai phụ trong nghiên cứu của Kiattisak K. chỉ là 307, thấp hơn nhiều so với nhiên cứu của chúng tôi.

\section{KẾT LUÂ̂N}

Độ dài CTC trung bình của thai phụ từ 19-23 tuần là $35,8 \pm 5,5 \mathrm{~mm}$. Không có sự khác biệt về độ dài CTC trung bình giữa các tuần thai.

Có sự khác biệt về độ dài CTC trung bình giữa 2 nhóm thai phụ đẻ đủ tháng và nhóm thai phu có tiền sử đẻ non. Độ dài CTC trung bình ở nhóm có tiền sử đẻ non ngắn hơn có ý nghĩa thống kê so với nhóm phụ đẻ đủ tháng. Những thai phụ có độ dài CTC ngắn có nguy cơ đẻ non cao gấp 4 lần so với nhóm có độ dài CTC bình thường (OR=4; 95\%CI: 2,2-7,6).

Tỷ lệ thai phụ có độ dài CTC ngắn $(\leq 25 \mathrm{~mm})$ trong nghiên cứu là 1,9\%. Tuy nhiên để có một con số chính xác hơn về tỉ lế thai phụ Viêt Nam có độ dài CTC ngắn, cần có những nghiên cứu có số lượng cỡ mâu lớn hơn.

\section{TÀI LIÊU THAM KHẢO}

1. WHO (2018), Preterm birth, www.who.int.

2. Liu L., Oza S., Hogan D., et al. (2016). Global, regional, and national causes of under- 5 mortality in 2000-15: an updated systematic analysis with implications for the Sustainable Development Goals. Lancet, 388(10063), 3027-3035.

3. Kenneth Lim and Joan M. Crane K.B. (2018). No. 257-Ultrasonographic Cervical Length Assessment in Predicting Preterm Birth in Singleton Pregnancies. Journal of Obstetrics and Gynaecology Canada, 40(2), 151-164.

4. Neoma Withanawasam S.T. (2019). The shortened cervix in pregnancy: Investigation and current management recommendations for primary caregivers. Australian Journal of General Practice, 48(3), 12-15.

5. Fonseca EB, Celik E, Parra $M$, Singh $M$, Nicolaides KH. (2007). Progesterone and the risk of preterm birth among women with a short cervix. The New England journal of medicine, 357(5), 462-9.

6. Blencowe H., Cousens S., Oestergaard M.Z., et al. (2012). National, regional, and worldwide estimates of preterm birth rates in the year 2010 with time trends since 1990 for selected countries: a systematic analysis and implications. Lancet, 379(9832), 2162-2172.

7. FIGO COMMITTEE REPORT (2015). Best practice in maternal-fetal medicine. International Journal of Gynecology and Obstetrics, 128, 80-82.

8. Nguyến Công Định (2009), Nghiên cứu đo độ dài cổ tử cung ở phụ nữ có thai 20 - 24 tuần bằng phương pháp siêu ầm tầng sinh môn, Luân văn Thạc sỹ Y học, Đại học Y Hà Nội.

9. Buck J.N., Orzechowski K.M., and Berghella V. (2017). Racial disparities in cervical length for prediction of preterm birth in a low risk population. The Journal of Maternal-Fetal \& Neonatal Medicine, 30(15), 1851-1854.

\title{
ĐẶC ĐIỂM LÂM SÀNG, CÂ̂N LÂM SÀNG HộI CHỨNG CAI RƯợU NẶNG ĐIỀU TRI TẠI TRUNG TÂM CHỐNG ĐộC BỆNH VIỆN BẠCH MAI
}

\section{TÓM TẮT}

Mục tiêu: Nhận xét đặc điểm lâm sàng, cận lâm sàng hô̂i chứng cai rượ năng. Đối tượng và phương pháp: Ṅghiên cứu mô tả trên 38 bệnh nhân có hội chứng cai rươu nặng với điểm CIWA-Är $\geq 20$ điều trị tại Trung tâm chống độc bệnh viện Bạch Mai từ 1/2018 đến tháng 7/2018. Kết quả: $100 \%$ gặp ở nam giới:

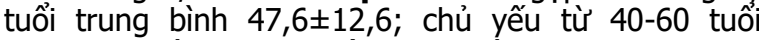
$(68,4 \%)$, thời gian nghiên rượu dài $18,7 \pm 8,55$ năm; uống $500-700 \mathrm{ml} / \mathrm{ngày}$ tới $63,2 \%$; hội chứng cai kéo dài trung bình 3,8 ngày. Đặc điểm lâm sàng: bệnh nhân có đầy đủ các dấu hiệu nặng theo thang điểm CIWA-Ar: dấu hiệu run (100\%), l̇o âu $(100 \%)$, vã mồ

${ }^{1}$ Trung Tâm Chông Độc, Bệnh viện Bạch Mai

2Trung tâm Cấp cứu, Bênh viện Bach Mai

Chịu trách nhiệm chính: Đặng Thị Xuân

Email: xuandangthi17@gmail.com

Ngày nhân bài: 12.01.2021

Ngày phản biên khoa hoc: 15.3.2021

Ngày duyệt bài: 23.3.2021

\section{Đặng Thị Xuân ${ }^{1}$, Đỗ Ngọc Sơn ${ }^{2}$}

hôi $(97,4 \%)$, kích động $(92,1 \%)$, buồn nôn và nôn $(28,9 \%)$, đau đâu $(15,8 \%)$. Các rối loạn ảo giác: thính giác $(92,1 \%)$, thị giác $(89,5 \%)$, xúc giác $(23,7 \%)$. Rối loạn định hướng ở $76,3 \%$ số bệnh nhân. Biến chứng viểm phổi $(39,5 \%)$ và $15,8 \%$ số BN phải thở máy. Đăc điểm cận lâm sàng: Tăng CK, AST, ALT, lactat. Kết luận: Hội chứng cai rượu nặng với nhiều triệu chứng và biến chứng, cần hồi sức và điều trị tại các đơn vị hồi sức tích cực.

Tư khóa: hội chứng cai, thang điểm CIWA-Ar.

\section{SUMMARY}

CLINICAL AND LABORATORY CHARACTERISTICS OF SEVERE ALCOHOL WITHDRAWAL SYNDROME

Objective: to assess clinical features and laboratory abnormalities of severe alcohol withdrawal syndrome. Subjects and Methods: An observational study on 38 patients with severe alcohol withdrawal syndrome (CIWA-Ar score $\geq 20$ ) treated at Poison Control Center of Bach Mai Hospital from January 
2018 to July 2018. Results: The study patients were all male $(100 \%)$, the mean age was $47.6 \pm 12.6$ years old, mainly from 40 to 60 years old $(68.4 \%)$, the average duration of alcoholism was $18.7 \pm 8.55$ years; $63.2 \%$ had drunk $500-700 \mathrm{ml} /$ day. The alcohol withdrawal syndrome lasted for an average of 3.8 days. Clinical features: patient admitted to hospital had all signs in CIWA-Ar score: tremor (100\%), anxiety $(100 \%)$, sweating $(97.4 \%)$, agitation $(92.1 \%)$, nausea and vomiting $(28.9 \%)$, headache $(15.8 \%)$. Psychiastric disorders: delusion of hearing (92.1\%), vision $(89.5 \%)$, touch $(23.7 \%)$. Orientation disorder in $76.3 \%$ of patients. Complications of pneumonia (39.5\%) and $15.8 \%$ of patients must be ventilated. Laboratory features: Increased CK, AST, ALT, lactate. Conclusion: Severe alcohol withdrawal syndrome present many serious symptoms and complications, requiring resuscitation and treatment in intensive care units.

Keywords: severe alcohol withdrawal syndrome, CIWA-Ar score.

\section{I. ĐĂT VẤN ĐỀ}

Rượu là đồ uống được sử dụng rộng rãi vì vậy nghiện rượu là bệnh tương đối phổ biến trên trên toàn thế giới. Tại Hoa Kỳ, khoảng 17 triệu người trưởng thành có tiền sử lạm dụng rượu [4]. Việt Nam đang tiêu thụ gần 68 triệu lít rượu mối năm, đứng ở vị trí 29 trên thế giới về chỉ số sử dụng rượu, bia; tỷ lệ dân số sử dụng rượu, bia ngày càng trẻ hóa với độ tuổi 14-17 là $47,5 \%$ và trong độ tuổi $18-21$ là $67 \%$ [1].

Hội chứng cai rượu cấp là bệnh lý đặc biệt xuất hiện trên nền người nghiện rượu, vì một lý do nào đó mà đột ngột bỏ rượu, xuất hiện các triệu chứng và rối loạn đặc biệt. Có tới $25 \%$ bệnh nhân nhập viện có lạm dụng rượu bị hội chứng cai rượu cấp, trong đó $16-31 \%$ có co giật, sảng rung cần phải điều trị tại đợn vị hồi sức. Tỷ lệ tử vong của bệnh nhân có hội chứng cai rượu không được điêu trị là $15 \%$ và được điều trị là 2\%. Các bệnh nhân nằm ở ICU có hội chứng cai rượu có nguy cơ tử vong cao hơn, nằm ICU lâu hơn, thở máy dài hơn, chi phí điều trị cao hơn so với bệnh nhân nằm ICU mà không có hội chứng cai rượu [2],[3].

Để thống nhất trong chẩn đoán mức độ, các tác giả đã đưa ra một số bảng điểm đánh giá mức độ nặng. Các tác giả ở Mỹ đưa ra bảng điểm CIWA-Ar (Clinical Institute Withdrawal Assessment Scale for Alcohol) để đánh giá mức độ nặng của hội chứng cai rượu, tổng điểm tối đa là 67 , đánh giá mức độ nặng khi trên 20 điểm [4]. Với tình hình sử dụng rượu bia nhiều như ở nước ta thì nghiện rượu và bệnh lý do cai rượu là vấn đề thường xuyên gặp ở các cơ sở y tế. Việc đánh giá mức độ nặng, triệu chứng thường gặp của hội chứng cai rượu nặng theo theo lâm sàng, bảng điểm CIWA-Ar, giúp các bác sĩ hồi sức chống độc áp dụng biện pháp can thiệp phù hợp, giảm biến chứng và tử vong. Ở Việt Nam còn thiếu đánh giá về hội chứng cai rượu nặng ở các đơn vị hồi sức. Vì vậy chúng tôi tiên hành nghiên cứu đề tài với mục tiêu "Nhận xét đặc điểm lâm sàng, cận lâm sàng hội chứng cai rượu nặng"tại Trung tẩm chống độc Bv Bạch Mai.

\section{II. ĐỐI TƯỢNG VÀ PHƯƠNG PHÁP NGHIÊN CỨU}

2.1. Đối tượng nghiên cứu: Bênh nhân được chẩn đoán hội chứng cai rượu nặng được điều trị tại Trung tầm chống độc Bệnh viện Bạch Mai trong thời gian từ tháng 1/2018 đến tháng 7/2018 theo tiêu chuẩn sau:

- Tiên sử nghiện rượu được chẩn đoán theo ICD 10.

- Chẩn đoán hội chứng cai rượu: theo DSM-5 [4]

Ngừng hoặc giảm đáng kể lượng rượu uống khi đang sử dụng rượu liều cao và kéo dài.

Có ít nhất 2 tiêu chuẩn dưới đây xảy ra sau tiêu chuẩn $A$ vài giờ đến vài ngày.

- Tăng hoạt động tự động.

- Run tay.

- Mất ngủ.

- Nôn, buồn nôn.

- Lo âu quá mức.

- Kích động.

- Ảo thị giác, ảo thanh, hoặc hoang tưởng.

- Cơn co giật kiểu động kinh.

Các triệu chứng ở tiêu chuẩn $B$ gây suy giảm rõ rệt các chức năng xã hội, nghề nghiệp hoặc các lî̃nh vực quan trọng khác

Các triệu chứng này không do một bệnh thực tổn và một bệnh rối loạn tâm thần khác gây ra.

- Có điểm CIWA-Ar $\geq 20$ [5]

Tiêu chuẩn loại trừ

- Bệnh nhân hoặc người đại diện từ chối tham gia nghiên cứu.

- Bệnh lý thần kinh trung ương: máu tụ nội sọ, viêm màng não ...

- Có tiền sử bệnh tâm thần hay động kinh.

\subsection{Phương pháp nghiên cứu}

Thiết kế nghiên cứu: nghiên cứu mô tả tiến cứu.

Cỡ mẫu: Cõ̃ mẫu thuận tiện.

Tiến hành nghiên cứu: thu thập thông tin theo mẫu bệnh án nghiên cứu

Đặc điểm chung của nhóm BN nghiên cứu địa chỉ.

- Đặc điểm chung: tuổi, giới, nghề nghiệp,

- Tiền sử nghiện rượu: thời gian nghiện, số lượng rượu uống trong ngày $(\mathrm{ml})$.

- Tiền sử bệnh tật, bệnh lý gan, thần kinh trước đó.

- Yếu tố khởi phát (lí do ngừng uống rượu) 
- Thời gian ngừng uống rượu khi vào Trung tâm Chống độc:

\section{Đặc điểm lâm sàng}

- Lâm sàng: Glasgow, mạch, huyết áp, nhịp thở, nhiệt độ, SpO2.

- Buồn nôn, nôn.

- Lo âu.

- Run (bàn tay, chi trên, toàn thân).

- Vã mồ hôi: gan bàn tay, gan bàn tay + trán, toàn thân.

- Kích thích

- Ảo giác: ảo thanh, ảo thị, ảo giác xúc giác.

- Đau đâu.

- Rối loan đinh hướng.

- Đánh giá theo thang điểm CIWA-Ar.

- Cận lâm sàng: Công thức máu, đông máu cơ bản, ure, creatinin, glucose, AST, ALT, Bilirubin, Protid/Albumin, Bilirubin, CK, khí máu, lactat, điện giải đồ, Xquang tim phổi, điện tim. Các xét nghiệm thăm dò khác theo tình trạng bệnh nhân: CT sọ não, điện não đồ, chọc dịch nã̃o tủy, cây máu, cấy dịch.

2.3. Xử lí số liệu. Số liệu được xử lý theo phương pháp thống kê y học, sử dụng phần mềm SPSS 20.0. So sánh giá trị 2 trung bình bằng Student test (Mann-Witney $U$ test nếu phân bố không chuẩn), so sánh tỉ lệ \% bằng test X2 hoặc Fisher Exact test, mức ý nghĩa thống kê 95\%.

\section{KẾT QUẢ NGHIÊN CứU}

Trong thời gian từ $1 / 2018-8 / 2018$ có 38 bệnh nhân điều trị tại Trung tâm Chống độc Bệnh viện Bạch Mai có hội chứng cai rượu nặng đủ tiêu chuẩn nghiên cứu

\section{1. Đăc điểm chung của bênh nhân} nghiên cứu

- Phân bố theo giới: 100\% BN là nam giới

- Phân bố theo tuổi: tuổi trung bình là $48,1 \pm 9,23$ (26-66), đa số từ 40-60 tuối $(68,4 \%)$.

- Thời gian nghiện rượu: trung bình 18,7 \pm 8,55 năm (5-30). Thời gian nghiện rượu 11-20 năm $(36,8 \%)$, từ 5-10 năm và 21-30 năm đều là $31,6 \%$.

- Lượng rượu uống hàng ngày: trung bình $565,8 \pm 266,38 \mathrm{ml} / \mathrm{ngày}$ (200-1500). Uống từ $500-700 \mathrm{ml} / \mathrm{ngày}$ chiếm tỷ lệ cao nhất $(63,2 \%)$.

- Nguyên nhân xuất hiện hội chứng cai rượu: tự bỏ rượu 13BN $(34,2 \%)$, do nhiếm trùng $10 \mathrm{BN}$ $(26,3 \%), 8 \mathrm{BN}(21,1 \%)$ điêuu trị ngộ độc rượu và xuất hiện hội chứng cai trong bệnh viện...

- Thời gian từ khi ngừng rượu đến khi vào viện: trung bình $3,3 \pm 1,5$ ngày, có tới $50 \%$ sau ngừng rượu 4 -5 ngày.

- Thời gian hội chứng cai rượu: kéo dài trung bình 3,8 ngày.

\section{2. Đặc điểm lâm sàng, cận lâm sàng của hội chứng cai rượu nặng}

Bảng 3.1. Dấu hiệu sinh tồn lúc vào viện

\begin{tabular}{|c|c|c|c|c|c|c|}
\hline & $\begin{array}{c}\text { Mach } \\
\text { (ck/phút) }\end{array}$ & $\begin{array}{l}\text { HA tối đa } \\
\text { (mmHg) }\end{array}$ & $\begin{array}{l}\text { HA tối thiểu } \\
\text { (mmHg) }\end{array}$ & $\begin{array}{c}\text { Nhiệt độ } \\
\left({ }^{\circ} \mathrm{C}\right)\end{array}$ & $\begin{array}{l}\text { Nhịp thở } \\
\text { (lân/phút) }\end{array}$ & $\begin{array}{l}\mathrm{SpO}_{2} \\
(\%)\end{array}$ \\
\hline Trung bình & $105,9 \pm 20,9$ & $127,9 \pm 19,61$ & $77,1 \pm 11,60$ & $37,2 \pm 0,66$ & $18,7 \pm 3,82$ & $95,6 \pm 5,57$ \\
\hline
\end{tabular}

Nhận xét: Bệnh nhân cai rượu có tình trạng mạch nhanh và tăng thông khí nhẹ lúc vào viện.

\section{- Đặc điểm triệu chứng trong thang điểm CIWA-Ar}
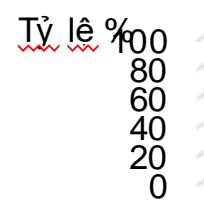

Buồn nôn và nôn

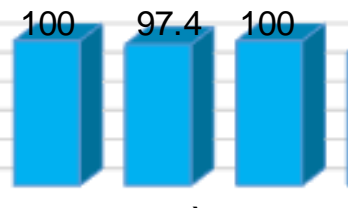

Run Vã mồ Lo âu hôi

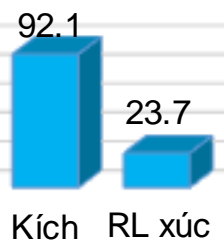

động giác

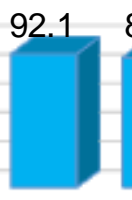

$\mathrm{RL} \quad \mathrm{RL}$ thị tính giác giác

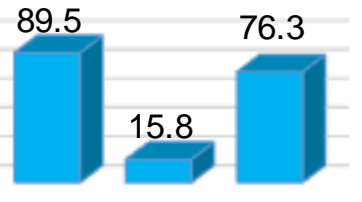

Đau $\mathrm{RL}$ đầu định hướng

\section{Biểu đồ 3.1. Các dấu hiệu CIWA-Ar khi nhập viện}

- Lượng rượu uống trong ngày có mối tương quan với điểm CIWA-Ar các ngày điều trị thứ 2,3 $(p<0,01)$ và liều diazepam điêu trị trong các ngày 2 và $3(p<0,01)$.

Nhận xét: Bệnh nhân vào viện có đầy đủ các dấu hiệu của thang điểm CIWA-Ar. Các dấu hiệu run, lo âu (100\%), vã mồ hôi $(97,4 \%)$, kích động $(92,1 \%)$ gặp ở hầu hết bệnh nhân. Các dấu hiệu buồn nôn, nôn xuất hiện ở $28,9 \%$, đau đầu $15,8 \%$ là ít xuất hiện nhất. Trong các ảo giác bệnh nhân gặp phải thì chủ yếu là các rối loạn thính giác $(92,1 \%)$ và thị giác $(89,5 \%)$, rối loạn về xúc giác ít gặp hơn (23,7\%). Rối loạn định hướng gặp ở 76,3\% bệnh nhân. 


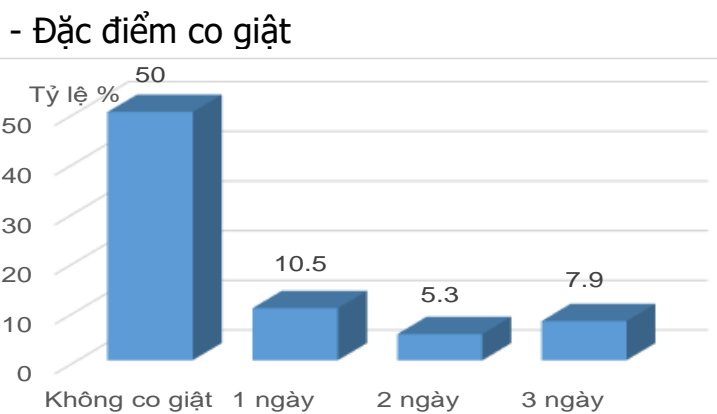

Biểu đồ 3.2. Tình trạng co giật ở bệnh nhân cai rươu năng

Nhận xét: Có 19/38 (50\%) bệnh nhân xuất hiện co giật, xuất hiện sau ngừng uống rượu trung bình là 2,0 $\pm 0,62$ ngày (sớm nhất là 1 ngày, muộn nhất là 3 ngày).

Bảng 3.2. Tình trạng viêm phổi, thở máy khi nhập viện

\begin{tabular}{|c|c|c|c|c|}
\hline \multirow{2}{*}{} & \multicolumn{2}{|c|}{$\begin{array}{c}\text { Viêm phối khi } \\
\text { vào viện }\end{array}$} & \multicolumn{2}{c|}{$\begin{array}{c}\text { Thở máy khi } \\
\text { vào viện }\end{array}$} \\
\cline { 2 - 5 } & Số BN & $\mathbf{\%}$ & Số BN & \% \\
\hline Không & 23 & 60,5 & 32 & 84,2 \\
\hline Có & 15 & 39,5 & 6 & 15,8 \\
\hline Tống & $\mathbf{3 8}$ & $\mathbf{1 0 0}$ & $\mathbf{3 8}$ & $\mathbf{1 0 0}$ \\
\hline
\end{tabular}

Nhận xét: - Có $15 / 38$ BN $(39,5)$ khi nhập viện đã có viêm phổi.

- Có 6/38 BN (15,8\%) khi nhập viện có suy hô hấp, phải đặt ống nội khí quản, thở máy.

Bảng 3.4. Sự thay đổi sinh hóa, khí máu động mạch trước và sau điều trị

\begin{tabular}{|c|c|c|c|}
\hline Chỉ số & $\begin{array}{l}\text { Lúc vào } \\
\text { viên (1) }\end{array}$ & $\begin{array}{l}\text { Lúc ra } \\
\text { viên (2) }\end{array}$ & $\begin{array}{l}\mathbf{p}^{(1)} \\
\text { và (2) }\end{array}$ \\
\hline GOT (U/L) & 174,5 & 108 & $<0,001^{*}$ \\
\hline GPT (U/L) & 64,5 & 52 & $<0,01^{*}$ \\
\hline CK & 1692,5 & 433,0 & $<0,001^{*}$ \\
\hline $\begin{array}{l}\text { Bilirubin toàn } \\
\text { phần }(\mu \mathrm{mol} / \mathrm{L})\end{array}$ & 27,4 & 11,4 & $<0,001 *$ \\
\hline Lactat $(\mathrm{mmol} / \mathrm{L})$ & $3,2 \pm 1,44$ & $1,04 \pm 0,42$ & $<0,001$ \\
\hline $\mathrm{pH}$ & $7,44 \pm 0.83$ & $7,45 \pm 0,04$ & $>0,05$ \\
\hline $\mathrm{PaCO}_{2}(\mathrm{mmHg})$ & $32,3 \pm 5,74$ & $36,1 \pm 3,82$ & $<0,05$ \\
\hline $\mathrm{PaO}_{2}(\mathrm{mmHg})$ & $92,0 \pm 24,16$ & $102,1 \pm 28,80$ & $>0,05$ \\
\hline $\mathrm{HCO}_{3}-(\mathrm{mmol} / \mathrm{l})$ & $22,5 \pm 4,67$ & $25,1 \pm 2,42$ & $>0,05$ \\
\hline
\end{tabular}

(*Mann-Witney U test)

Nhận xét: - Các chỉ số AST, ALT, CK, lactat máu đều tăng khi vào viện, giảm rất rõ khi bệnh nhân ra viện, $\mathrm{p}<0,01$

- Thay đổi của $\mathrm{pH}, \mathrm{PaO}_{2}, \mathrm{HCO}_{3}^{-}$lúc ra viện không khác so với lúc vào viện, chỉ có $\mathrm{PaCO}_{2}$ tăng nhẹ $(p<0,05)$.

\section{BÀN LUẬN \\ 4.1. Đặc điểm chung của bệnh nhân nghiên cứu}

\subsubsection{Lúa tuổi}

- Phân bố theo tuổi: Tuổi trung bình các bệnh nhân của chúng tôi là 48,1 $\pm 9,23$ (26-66), đa số bệnh nhân là từ 40-60 tuổi $(68,4 \%)$. Nhiều tác giả đều nhận thấy độ tuổi hội chứng cai rượu thường gặp ở độ tuổi trung niên. Theo Phan Vằn Tiếng lứa tuổi $31-40$ là $42,5 \%$ từ 41-50 tuổi $32,5 \%$ còn từ $51-60$ tuổi là $20 \%$ [6]. Theo Sarkar độ tuổi thường gặp là 42,85 $\pm 10,92$ [9].

- Giới tính: $100 \%$ bệnh nhân cai rượu của chúng tôi là nam giới. Các nghiên cứu trong và nước ngoài đều thấy tỉ lệ bệnh nhân nam là chủ yếu [7],[8]. Thực tế ở Việt Nam, nữ giới ít uống rượu hơn nam rất nhiều nên các bệnh lý liên quan tới rượu gặp chủ yếu là nam giới.

- Thời gian nghiện rượu: chúng tôi thấy thời gian nghiện rượu trung bình là $18,7 \pm 8,55$ năm (từ 5-30 năm). Trong đó, cao nhất là từ 1120 năm $(36,8 \%)$, từ 5-10 năm và 21-30 năm đều là $31,6 \%$. Theo Ngô Chí Hiếu nhóm nghiện rượu từ 10 - 15 năm chiếm 58,53\%, 15 - 20 năm chiếm 29,27\%[7]. Thời gian nghiện rượu dài, kèm theo đó sẽ là các bệnh mạn tính như xơ gan, bệnh đường tiêu hóa.

- Lượng rượu uống hàng ngày: trung bình $565,8 \pm 266,38 \mathrm{ml} / \mathrm{ngày}$ (200-1500). Uống từ $500-700 \mathrm{ml} /$ ngày chiếm tỷ lệ cao nhất $(63,2 \%)$, $100-400 \mathrm{ml} /$ ngày $\quad 21,1 \% ; \quad 800-1000 \mathrm{ml} /$ ngày $13,2 \%$ và $>1000 \mathrm{ml} /$ ngày là $3,2 \%$.

- Các nguyên nhân bỏ rượu dẫn đến hôii chứng cai rượu: chúng tôi thấy nhiều nhất là tự bỏ rượu 13BN $(34,2 \%)$, do nhiếm trùng $10 \mathrm{BN}$ (26,3\%), một vài nguyên nhân khác là do chấn thương hoặc bị bệnh tật. Đặc biệt, chúng tôi có 8 BN $(21,1 \%)$ trong khi điêu trị bị ngộ độc rượu, vì ngừng uống rượu nên xuất hiện hội chứng cai: trong đó 2 BN nặng hôn mê sâu suy hô hấp phải đặt nội khí quản thở máy, $1 \mathrm{BN}$ ngộ độc methanol nặng phải thở máy và lọc máu, khi ngộ độc methanol ổn định rút nội khí quản được 12 giờ thì xuất hiện hội chứng cai. Điều này cho thấy sự đa dạng của các nguyên nhân gây hội chứng cai rượu cũng như ngoài việc điều trị hội chứng cai rượu còn phải điêu trị các bệnh lý là nguyên nhân khởi phát và bệnh đi kèm. Ngô Chí Hiếu hội chứng cai rượu xuất hiện do viêm họng (37,9\%), nôn-đau thượng vị (30,4\%), 26,7\% xuất hiện khi nhập viện điêu trị các bệnh lý khác [7].

- Thời gian từ ngừng uống rượu đến khi xuất hiện sảng rượu là $3,3 \pm 1,5$ ngày. Thực tế, các bệnh nhân cai rượu vào Trung tâm chống độc trong khoảng thời gian diễn biến nặng của bệnh.

- Thời gian tôn tại hội chứng cai rượu của chúng tôi là $3,8 \pm 2,24$ ngày ngắn hơn của tác giả Ngô Chí Hiếu là 4,63 $\pm 3,15$ ngày [7], 
nhiều khả năng do chúng tôi sử dung phác đồ kết hợp diazepam và phenobarbital nên giảm thời gian sử dụng an thần cho bệnh nhân.

4.2. Vê đăc điểm lâm sàng và cân lâm sàng - Dấu hiệu sống và đặc điểm lâm sàng theo thang điểm CIWA-Ar. Bệnh nhân vào viện có đầy đủ các dấu hiệu của thang điểm CIWA-Ar: Nhóm dấu hiệu gặp nhiều nhất là: run $(100 \%)$, lo âu $(100 \%)$, vã mồ hôi $(97,4 \%)$, kích động $(92,1 \%)$. Các dấu hiệu buồn nôn, nôn ở $28,9 \%$ số BN, đau đầu là $15,8 \%$. Trong các ảo giác bệnh nhân gặp phải thì chủ yếu là các rối loạn thính giác $(92,1 \%)$ và thị giác $(89,5 \%)$, rối loạn về xúc giác ít gặp hơn (23,7\%). Rối loạn định hướng gặp ở 76,3\% bệnh nhân.

Khi đánh giá về mức độ các triệu chứng chúng tôi thấy: triệu chứng run chủ yếu là run từ vừa đến nặng (52,6\% và $44,7 \%)$; vã mồ hôi mức độ vừa ở bàn tay và trán chiếm $55,3 \%$, lo âu nhẹ $(57,9 \%)$, bệnh nhân kích động nhe và vừa là chủ yếu ( $50 \%$ và $39,5 \%)$. Các rối loạn thính giác và thị giác thường đi kèm với nhau. Các rối loạn định hướng ở bệnh nhân chủ yếu rối loạn về thời gian và không gian, không gặp rối loạn định hướng về bản thân. Ngoài ra, số lượng rượu uống trong ngày có mối tương quan với điểm CIWA-Ar các ngày điều trị thứ $2,3(\mathrm{p}<$ 0,01 ) và liều diazepam điều trị trong các ngày 2 và $3(p<0,01)$. Như vậy có mối liên quan giữa mức độ nặng của bệnh nhân với lượng rượu uống hàng ngày và liều diazepam.

Khi vào viện chúng tôi có $15 / 38 \mathrm{BN}(39,5 \%)$ đã viêm phổi, trong đó 6 BN $(15,8 \%)$ phải thở máy. Đây chính là một trong những biến chứng năng mà làm cho bệnh nhân cần phải điều trị tại các đơn vị hồi sức.

Đánh giá về đặc điểm lâm sàng, tác giả Phan Văn Tiêng nhận thấy bệnh nhân có triệu chứng mất ngủ gặp ở $100 \%$ số $B N$, run $(100 \%)$, toát mồ hôi $(100 \%)$, mệt mỏi $(82,5 \%)$, đau đầu $(77,5 \%)$, chán ăn $(77,5 \%)$, thèm rượu $(45,5 \%)$, bồn chồn $(52,5 \%)$, huyết áp tăng $(37,5 \%)$, buồn nôn $(25 \%)$, nôn $(15 \%)$, thở nhanh (15\%). Rối loạn định hướng không gian(100\%), xung quanh $(100 \%)$, thời gian $(95 \%)$, bản thân $(15 \%)$. Trong các triệu chứng lo âu của các bệnh nhân: lo lắng $(90 \%)$, hoảng sợ $(77,5 \%)$, ác mộng $(22,5 \%)$, bồn chồn bất an $(22,5 \%)$. Triệu chứng kích động $(77,5 \%)$, ảo thị chiếm $(95, \%)$ cao hơn, ảo xúc (50\%), ảo thính (37,5\%) [6]. Các triệu chứng khá nhiều, tuy nhiên không có các bệnh nhân nặng phải hồi sức và thở máy như của chúng tôi.
- Đặc điểm co giật: Theo một số tác giả, co giật thường xuất hiện sau ngừng uống rượu 6-48 giờ ở $\mathrm{BN}$ nghiện rượu, khoảng $10 \% \mathrm{BN}$ cai rượu bị co giật. Ngô Chí Hiếu thấy khởi phát hội chứng cai rượu bằng các cơn co giật chiếm 21,95\% [7] và Phan Văn Tiếng có $32,5 \%$ BN cai rượu có cơn co giật toàn thể [6].

Trong nghiên cứu của chúng tôi có đến 19/38 BN $(50 \%)$ có cơn co giật là khởi phát hội chứng cai rượu. Tỉ lệ co giật của chúng tôi cao hơn các tác giả vì là những bệnh nhân có hội chứng cai rượu nặng, điều trị tại phòng hồi sức của Trung tâm. Những bệnh nhẩn có co giật, chúng tôi đều cho làm xét nghiệm và thăm dò phù hợp để chẩn đoán và tìm nguyên nhân như: chụp CT sọ não, ghi điện não đồ, chọc dịch não tủy, cấy dịch... Các bệnh nhân thường chỉ co giật 1 lần khi khởi phát hội chứng cai và là nguyên nhân đi khám bệnh, hiếm có co giật xuất hiện trở lại trong thời gian điều trị. Các kết quả xét nghiệm và thăm dò không thấy tổn thương và rối loạn. Chúng tôi có 1 bệnh nhân vào viện có tình trạng co giật toàn thể liên tục, kích động dữ dội phải kiểm kiểm soát co giật bằng diazepam, phenobarbital và cả propofol, đặt nội khí quản và thở máy. Theo Jesse có 3 - 5\% các bệnh nhân có giật do cai rượu tiến triển thành trạng thái động kinh [8].

- Dấu hiệu cận lâm sàng:

Đánh giá kết quả của một số xét nghiệm sinh hóa lúc vào viện chúng tôi thấy các chỉ số $A S T$, $A L T$, CK đều tăng cao và giảm rõ rệt khi bệnh nhân ra viện $(p<0,01)$. Xét nghiệm tăng $C K$ cũng gián tiếp cho thấy tình trạng sảng và run của bệnh nhân, làm tăng tổn thương và tiêu cơ vân. Cùng với tiêu cơ vân, bệnh nhân nôn, mất nước, tổn thương gan ở những bệnh nhân nghiện rượu... cũng là nguyên nhân làm tổn thương thận thường gặp ở các bệnh nhân hồi sức nói chung và bệnh nhân cai rượu nói riêng. Mắt khác lactat lúc vào viện tăng nhưng sau điều trị giảm rõ $(p<0,01)$ cũng cho thấy điều trị hỗ trợ và hồi sức hiệu quả, cải thiện tình trạng tưới máu và oxy cho tế bào. Tác giả Jesse cũng cho thấy kết quả tương tự [8].

Các BN của chúng tôi lúc vào viện nhịp thở khá nhanh là $18,7 \pm 3.8$ lần/phút với $\mathrm{PaCO}_{2}$ là $32,3 \pm 5,74 \mathrm{mmHg}$ trong khí máu động mạch, bệnh nhân có toan chuyển hóa với HCO3- là 22,5 $\pm 4,67 \mathrm{mmol} / \mathrm{L}$. Những rối loạn trên thường do sự kích động và tình trạng chung toàn thân gây nên. Sau điêu trị thay đổi về $\mathrm{PaCO} 2$ máu và lactat cải thiện rõ rệt $(p<0,01)$. 


\section{KẾT LUÂ̂N}

Đặc điểm lâm sàng, cận lâm sàng của bệnh nhân có hội chứng cai rượu nặng:

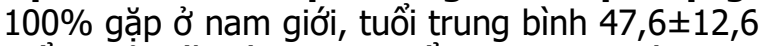
tuổi, chủ yếu từ 40-60 tuổi $(68,4 \%)$, thời gian nghiện rươu $18,7 \pm 8,55$ năm; tỉ lệ uống 500 $700 \mathrm{ml} / \mathrm{ngày}$ cao $(63,2 \%)$; hội chứng cai kéo dài trung bình 3,8 ngày.

Đăc điểm lâm sàng: Bệnh nhân có đầy đủ các dấu hiệu nặng theo thang điểm CIWA-Ar: dấu hiệu run (100\%), lo âu (100\%), vã mồ hôi $(97,4 \%)$, kích động $(92,1 \%)$, buồn nôn và nôn $(28,9 \%)$, đau đầu ít gặp nhất $(15,8 \%)$. Các rối loạn ảo giác: thính giác $(92,1 \%)$, thị giác $(89,5 \%)$, xúc giác $(23,7 \%)$. Rối loạn định hướng gặp ở 76,3\% bệnh nhân. Biến chứng viêm phổi $(39,5 \%)$ và $15,8 \%$ số phải thở máy. Cận lâm sàng: tăng lactat máu, lactat trung bình $3,2 \pm 1,44 \mathrm{mmol} / \mathrm{l}$, tăng CK, AST, ALT; cải thiện tốt khi bệnh nhân ra viện $(p<0,01)$.

\section{TÀI LIÊU THAM KHẢO}

1. Bộ Y Tế (2014). Báo cáo chung tổng quan ngành $Y$ tế năm 2014: Tăng cường dự phòng và kiểm soát bệnh không lây nhiễm. Nhà xuất bản Y học, 52

2. Deepali Dixit, Jeffrey Endicott, Lisa Burry et al (2016). Management of Acute Alcohol Withdrawal Syndrome in Critically Ill Patients. Pharmacotherapy: The Journal of Human Pharmacology and Drug Therapy, 36(7), 797-822.

3. Sarff M. and J. A. Gold (2010). Alcohol withdrawal syndromes in the intensive care unit. Crit Care Med, 38(9 Suppl), S494-501.

4. American Psychiatric Association (2013). Diagnostic and statistical manual of mental disorders $5^{\text {th }}$ (DSM-5®), American Psychiatric Pub. 2013.

5. Carol A Puz, Stokes SJ (2005). "Alcohol withdrawal syndrome: assessment and treatment with the use of the Clinical Institute Withdrawal Assessment for Alcohol-revised". Crit Care Nurs Clin North Am. 17 (3): 297-304.

6. Phan Văn Tiếng, Phạm Công Hòa, Nguyễn Văn Bảy (2011). Nhân xét kết quả điếu trị sảng rượu bằng diazepam tại Bệnh viện Tâm thần Trung ương 2.

7. Ngô Chí Hiếu, Nguyễn Thị Dụ (2003). Nghiên cứu đặc điểm lâm sàng, cận lâm sàng và hồi sức bênh nhhân có hôi chứng cai rượu. Luận văn thạc sî Trường Đại học Y Hà Nội.

8. Jesse S., G. Bråthen, M. Ferrara et al (2017). Alcohol withdrawal syndrome: mechanisms, manifestations, and management. Acta Neurologica Scandinavica, 135(1), 4-16.

\section{THỰC HÀNH PHÒNG CHỐNG TĂNG HUYẾT ÁP VÀ MỘT SỐ YẾU TỐ LIÊN QUAN Ở ĐỒNG BÀO CHĂM KHU VỰC NAM TRUNG Bộ}

\section{TÓM TẮT}

Xác định tỷ lệ thực hành đúng về phòng chống tăng huyểt áp và một số yếu tố liên quan ở đồng bào Chăm khu vực Nam Trung Bộ. Thiết kế cắt ngang mô tả được tiến hành trên 5.482 đồng bào Chăm từ 18 tuổi trở lên sinh sống tai 11 xã thuốc 4 tỉnh Ninh Thuận, Bình Thuận, Bình Định và Phú Yên từ tháng $10 / 2016$ đến tháng 10/2017. Kết quả cho thấy, tỷ lệ đồng bào Chăm có thực hành chung đúng về phòng chống tăng huyết áp còn thấp 23,6\%. Trong đó, tỷ lệ đồng bào Chăm không lam dụng rượu bia là 89,9\%, ăn ît mõ là $84,1 \%$, khống hút thuốc lá là $81,8 \%$, không ăn mặn là $52,7 \%$, có hoạt động thể lực là $67,2 \%$ và ăn đủ rau quả là $37,5 \%$. Mồt số yếu tố liên quan đến thực hành phòng chống tăng huyết áp đặc trưng ở đồng bào dân tộc Chăm được tìm thây gồm

${ }^{1}$ Bênh viện Quân Y 175

2Trường Đại họ Trà Vinh

${ }^{3}$ Viện Pasteur thành phố Hồ Chí Minh

Chịu trách nhiệm chính: Nguyễn Ngọc Huy

Email: huydr175@gmail.com

Ngày nhân bài: 25.01.2021

Ngày phản biên khoa hoc: 16.3.2021

Ngày duyệt bài: 23.3.2021
Nguyễn Ngọc Huy ${ }^{1}$, Nguyễn Văn Tập ${ }^{2}$, Trần Phúc Hậu ${ }^{3}$, Nguyễn Thanh Bình ${ }^{2}$

nhóm tuổi, trình độ học vấn, nghề nghiệp, tình trạng hôn nhân và kiến thức về phòng chống tăng huyết áp $(p<0,05)$. Cần có các can thiệp về phòng chống các yếu tố nguy cơ của tăng huyết áp cho đồng bào Chăm.

Tư khóa: Thực hành, tăng huyết áp, đồng bào dân tộc Chăm, Nam Trung Bộ

\section{SUMMARY \\ PRACTICE AND SOME FACTORS RELATED TO HYPERTENSION PREVENTION IN THE CHAM ETHNIC MINORITY IN THE SOUTH- CENTRAL REGION}

The study aimed to describe the good practices and some related factors to hypertension prevention in Cham ethnic minority 18 years of age or older in the South-Central Region. A cross-sectional study was conducted on 5.482 Cham people 18 years of age or older at 11 communes in Ninh Thuan, Binh Thuan, Binh Dinh and Phu Yen provinces from October 2016 to October 2017. The results showed that the prevalence of good practices on hypertension prevention in Cham minority group was low (23.6\%). In which, good practices on hypertension prevention with not abusing alcohol (89.9\%), less eating fat $(84.1 \%)$, not smoking $(81.8 \%)$, physical activity $(67.2 \%)$, not eating salty food $(52.7 \%)$, and eating 